\title{
Growth and Photoacclimation
} Strategies of Three Zostera Species Along a Vertical Gradient: Implications for Seagrass Zonation Patterns

\author{
Sang Rul Park ${ }^{1 *}$, Kyeonglim Moon ${ }^{1}$, Seung Hyeon Kim² and Kun-Seop Lee ${ }^{2}$ \\ ${ }^{1}$ Estuarine and Coastal Ecology Laboratory, Department of Marine Life Sciences, Jeju National University, Jeju-si, \\ South Korea, ${ }^{2}$ Department of Biological Sciences, Pusan National University, Busan, South Korea
}

OPEN ACCESS

Edited by:

Heliana Teixeira,

University of Aveiro, Portugal

Reviewed by:

Peter Anton Staehr,

Aarhus University, Denmark

Simone Strydom,

Department of Biodiversity,

Conservation and Attractions (DBCA),

Australia

*Correspondence:

Sang Rul Park

srpark@jejunu.ac.kr

Specialty section: This article was submitted to Marine Ecosystem Ecology, a section of the journal Frontiers in Marine Science

Received: 14 August 2020 Accepted: 14 January 2021

Published: 04 February 2021

Citation:

Park SR, Moon K, Kim SH and

Lee K-S (2021) Growth and Photoacclimation Strategies of Three

Zostera Species Along a Vertical Gradient: Implications for Seagrass Zonation Patterns.

Front. Mar. Sci. 8:594779. doi: 10.3389/fmars.2021.594779
Seagrasses typically display vertical zonation patterns in tropical and temperate areas. In East Asia, three Zostera species (Z. japonica, Z. marina, and Z. caespitosa) are distributed at different water depths, leading to zonation patterns from intertidal to subtidal zones. The present study aimed to determine whether these patterns could be explained by differences in their physiological responses, morphological traits, and meadows architecture caused by depth variations. Intertidal Zostera japonica had the lowest shoot height and blade width and the highest shoot density, while subtidal $Z$. caespitosa exhibited the largest specific leaf area. Total carotenoid content and the total chlorophyll/total carotenoid ratio were significantly higher in $Z$. japonica than in $Z$. marina or $Z$. caespitosa. The average carbon stable isotope $\left(\delta^{13} \mathrm{C}\right)$ values were significantly less negative in $Z$. caespitosa than in $Z$. marina and $Z$. japonica. The average maximum relative electron transport rate was higher for $Z$. marina than for $Z$. japonica and $Z$. caespitosa, while the maximum quantum yield values were higher for $Z$ caespitosa than for $Z$. japonica and $Z$. marina. The non-photochemical quenching (NPQ) of $Z$. japonica extinguished within 5-min following the rapid light curve, indicating that most of its NPQ was energy-dependent quenching (qE). The rapid light curve $(R L C)$ parameters and leaf relaxation after RLC showed that $Z$. japonica is a high-light adapted species and $Z$. caespitosa is a low-light adapted one. Additionally, $Z$. caespitosa showed the lowest dark respiration values and $Z$. japonica, the highest, suggesting that $Z$. caespitosa can survive with low photosynthetic activity. These results suggested that interspecific variations in the morphological and physiological characteristics, photosynthetic pigments, and meadows architecture of three Zostera species were associated with vertical zonation patterns and likely explain their patterns.

Keywords: vertical zonation pattern, three Zostera species, morphological and physiological acclimation, dark respiration, meadows architecture 


\section{INTRODUCTION}

Seagrasses are a specialized group of flowering plants adapted to marine environments and play crucial functional and structural roles in estuarine and coastal ecosystems (Kuo and McComb, 1989; Orth et al., 2006). They provide food and shelter that support the productivity and biomasses of commercially important fish species (Hemminga and Duarte, 2000; Beck et al., 2001; Short et al., 2007). Additionally, seagrass meadows are noted for their carbon-sink capacity (Nellemann and Corcoran, 2009). However, estuarine and coastal marine environments are undergoing unexpected and drastic changes such as nutrient enrichment, habitat destruction, rising temperatures, light reduction, and sea level rises due to anthropogenic and natural causes (Brierley and Kingsford, 2009; Short et al., 2016). Intertidal and shallow subtidal areas are highly susceptible to such environmental changes; thus, the distribution and abundance of seagrasses in these areas may be particularly vulnerable to such changes (Orth et al., 2006). Furthermore, climate change greatly accelerates environmental changes and, consequently, causes considerable changes in seagrass distributions (Duarte et al., 2018). Thus, understanding how seagrass species respond to environmental changes is critical for developing effective strategies to protect seagrass beds.

Seagrasses usually form single-species meadows or mixed vegetation areas with high species diversity in estuaries and lagoons and show specific zonation patterns from intertidal to subtidal areas in the temperate seagrass meadows (Short et al., 2007). Biotic factors such as grazing and interspecific competition affect seagrass zonation (Tribble, 1981; Williams, 1987). The morphological and physiological responses of seagrasses to local environmental conditions and stressors are well-studied (Zhang et al., 2015; Schubert et al., 2018; Soissons et al., 2018). For example, intertidal seagrasses exposed to excess light, desiccation stresses, and a wide temperature range had narrower leaves and a shorter canopy (Manassa et al., 2017). The increased shoot density of intertidal seagrass may be an adaptation to minimize emergence or desiccation stress (Yabe et al., 1996). Contrastingly, subtidal seagrasses increase the width and length of their leaves to enhance light capture under low light availability (Lee and Dunton, 1997; Collier et al., 2007). Moreover, seagrasses in intertidal and subtidal zones showed clearly different physiological responses to light conditions (Ralph et al., 1998; Park et al., 2016). These zonation patterns reflect their morphological and physiological adaptions to local environmental conditions and stressors, or their ability to occupy various niches (Björk et al., 1999; Tanaka and Nakaoka, 2004; Kaldy et al., 2015).

Intertidal seagrass species may be more exposed to excess irradiance, wide temperature ranges and desiccation stress than subtidal seagrass species due to tidal changes. The distribution limits of intertidal seagrass species may be determined by their adaptation or tolerance to air exposure, interspecific competition, light availability, and physical disturbance from tidal currents (Boese et al., 2005; Cabaço et al., 2009; Van der Heide et al., 2010). Leuschner et al. (1998) highlighted that the difference in desiccation tolerance between Zostera marina and $Z$. noltii allows them to have different depth distributions. Conversely, Z. japonica distributions in North America can be explained by temperature rather than desiccation tolerance and light limitation (Kaldy et al., 2015). In submerged seagrass beds, light availability determines seagrass depth distributions (Duarte, 1991). Since seagrasses require more light for growth and survival than other marine macrophytes, determining the threshold light levels for seagrass growth and survival is crucial for efficiently managing seagrass beds (Björk et al., 1999). For example, seagrasses respond to light intensity reductions by increasing their chlorophyll content, decreasing their chlorophyll $\mathrm{a} / \mathrm{b}$ ratio and reducing their production of ultraviolet (UV) lightblocking pigments to improve light capture and chemical energy conversion (Abal et al., 1994; Park et al., 2016). Additionally, the physiological responses of seagrasses to reductions in light intensity vary with temperature and, therefore, season as well (Collier et al., 2008; York et al., 2013). As the factors contributing to vertical zonation patterns show seasonal variations, it is essential to investigate the seasonal responses of seagrasses to evaluate the depth-related differences in their morphology and physiology.

Fifteen seagrass species are distributed in the temperate North Pacific region, where three genera (Zostera, Ruppia, and Phyllospadix) dominate (Short et al., 2007). In particular, the vertical patterns of five Zostera species ( $Z$. japonica, $Z$. marina, Z. caespitosa, Z. caulescens, and Z. asiatica) in Northeast Asia (China, Japan, and Korea) occur along waterdepth gradients (Aioi and Nakaoka, 2003; Lee and Lee, 2003). While $Z$. caulescens and $Z$. asiatica occur in relatively deep zones and form single-species meadows, $Z$. japonica, occurs in the intertidal zone, $Z$. marina grows to about $10 \mathrm{~m}$ depth, and $Z$. caespitosa reach $20 \mathrm{~m}$ depth in the temperate North Pacific region (Short et al., 2007). Additionally, three Zostera species form mixed vegetation areas (Lee et al., 2018). The intraspecific variations in the morphological and physiological characteristics of seagrasses along depth variations are relatively well-documented (Olivé et al., 2013; Park et al., 2016; Manassa et al., 2017). Contrastingly, the interspecific variations in their morphological and photosynthetic responses to environmental factors with respect to vertical zonation patterns are unclear (Huong et al., 2003; Tanaka and Nakaoka, 2007; Apichanangkool and Prathep, 2014; Shafer and Kaldy, 2014). Thus, further in situ studies and information on seagrass ecology and physiology are required to improve seagrass ecosystem management.

Here, we aimed to determine whether the observed vertical zonation patterns of three Zostera species could be explained by seasonal variations in physiological responses and morphological traits caused by depth variations. We hypothesized that morphological, meadow architectural, and physiological features of these species reflected depth-related environmental stressors such as light availability, temperature, and air exposure. This was done by examining their morphology, density, biomass, productivity, photosynthetic pigments, carbon stable isotope ratio, chlorophyll $a$ fluorescence parameters, and respiration rates. We also assessed light-dark relaxation kinetics to evaluate photosystem recovery upon high light exposure. Global climate change is a key driver of accelerating environmental change 


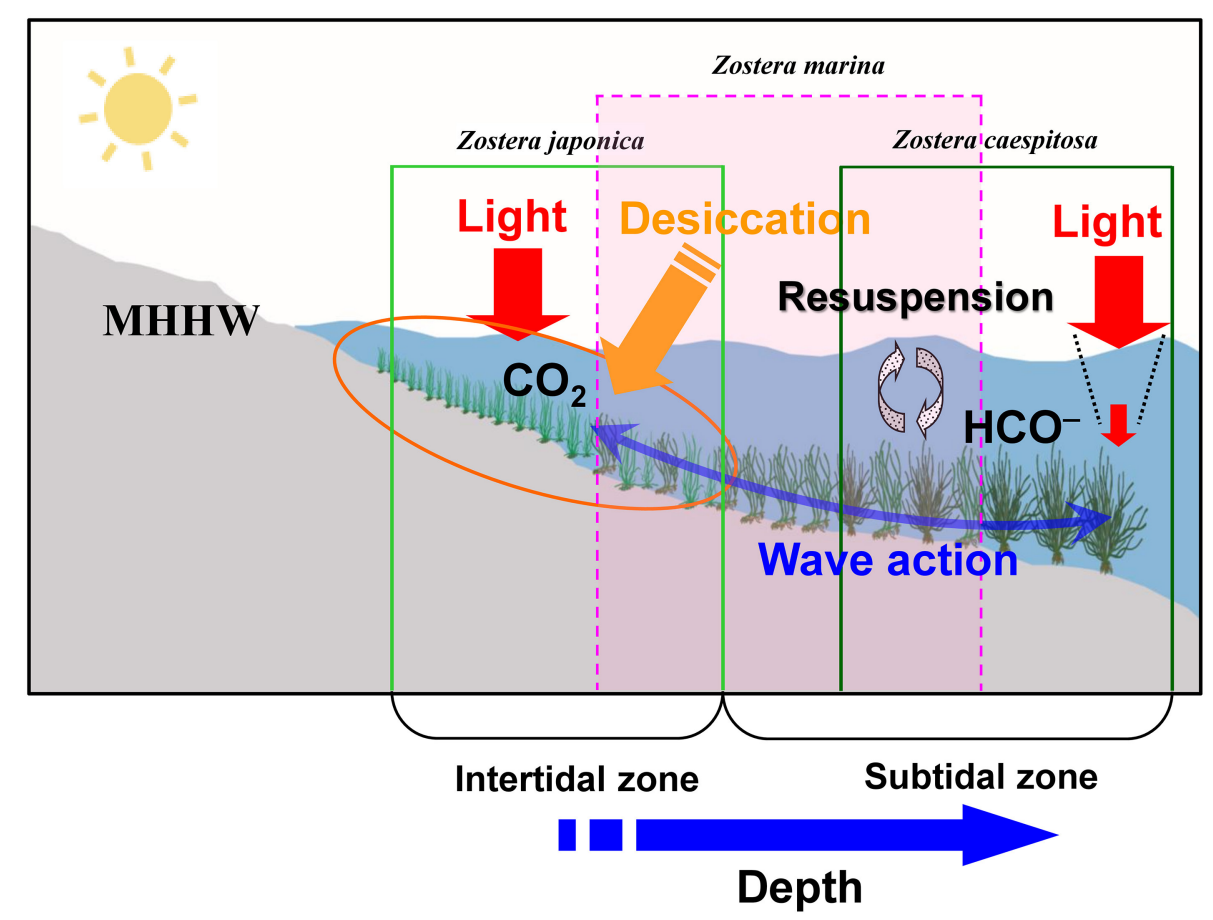

FIGURE 1 | Diagrams of three Zostera species (Z. japonica, Z. marina, and Z. caespitosa) zonation patterns and key features of environmental factors affected seagrass beds in Koje Bay along the southern coast of Korea. MHHW indicates Mean Higher High Water.

and consequently results in considerable changes in seagrass zonation. Thus, understanding how the three Zostera species respond to changing environmental conditions will help to predict their vertical zonation patterns in the temperate North Pacific region.

\section{MATERIALS AND METHODS}

\section{Study Area}

The study site was located in Koje Bay $\left(34^{\circ} 48^{\prime} \mathrm{N}, 128^{\circ} 35^{\prime} \mathrm{E}\right)$ on the southern coast of Korea, where three Zostera species (Z. japonica, $Z$. marina, and $Z$. caespitosa) are distributed sequentially from the intertidal zone to the shallow subtidal zone (Figure 1). The seagrass beds in Koje Bay consist of three monotypic meadows (Z. japonica, Z. marina, and Z. caespitosa) and two transition zones ( $Z$. japonicalZ. marina and $Z$. marinalZ. caespitosa). Zostera japonica meadows were distributed from the upper to lower intertidal zones (75-45 cm above the mean lower low water, MLLW) and were exposed to air at low tide. Zostera marina meadows grew in the lower intertidal (the lower distributional limit of $Z$. japonica) and upper subtidal (the upper distributional limit of $Z$. caespitosa) zones. In contrast, the $Z$. caespitosa beds occurred at an average water depth of $\sim 3.0-6.0 \mathrm{~m}$ relative to the MLLW. This study was performed in monotypic meadows of Z. japonica, Z. marina, and Z. caespitosa. Zostera japonica and $Z$. marina meadows were located at $63-67 \mathrm{~cm}$ and $15-20 \mathrm{~cm}$ above the MLLW, respectively, while $Z$. caespitosa were located at average water depths of $\sim 4.5-5.0 \mathrm{~m}$ relative to the MLLW. Water temperatures in Koje Bay ranged from 5.0 to $28.5^{\circ} \mathrm{C}$, and salinity ranged from 30.4 to 33.6 (Kim et al., 2015, 2016a; Suonan et al., 2017). Sandy sediments predominated at the study site. The tidal regime in the region is mixed semi-diurnal with a $3.0 \mathrm{~m}$ tidal range (Tide tables for the Coast of Korea, National Oceanographic Research Institute of Korea). The most extreme tidal range occurs in early spring, while the smallest tidal range in Summer. The summer monsoon rainy season and typhoons occur from mid-June through late-September.

\section{Light Irradiance and Exposure Time}

Light irradiance was monitored every $15 \mathrm{~min}$ using $\mathrm{HOBO}$ light intensity data loggers (Onset Computer Corp., Bourne, MA, USA) enclosed in clear submersible polycarbonate cases at the three study zones. The underwater sensors were cleaned regularly to minimize fouling. The light intensity (lumens $\mathrm{ft}^{-2}$ ) measured using the HOBO data loggers was converted to photon flux density (PFD; mol photons $\mathrm{m}^{-2} \mathrm{~s}^{-1}$ ) by concurrent quantum measurements using an LI-1400 data logger and an LI-193SA spherical quantum sensor (LI-COR, Lincoln, NE, USA). The HOBO data were calibrated to the LI-COR data using an exponential decay fit (Long et al., 2012). The HOBO measurements and PFD exhibited a relatively strong correlation $\left(r^{2}=0.90\right)$. Daily PFD $\left(\mathrm{mol} \mathrm{m}^{-2} \mathrm{~d}^{-1}\right)$ was calculated as the sum of quantum flux over each 24 -h period.

The tidal height at each zone was measured when the study zone began to be exposed to the air during low tide, and the air exposure time was calculated at each station using real-time tidal height data for the Korean coastline (Korea Hydrographic and Oceanographic Administration; http://www.khoa.go.kr). 
Monthly exposure time (h) was represented as the sum of total exposure time in each month.

\section{Morphology and Pigments}

To measure shoot morphological characteristics, 10-15 mature terminal shoots from each species were collected monthly from November 2005 to September 2006. Shoot height, sheath length and the width of the longest leaf were measured to the nearest $0.1 \mathrm{~mm}$. To determine the specific leaf area (SLA; $\mathrm{cm}^{2} \mathrm{~g}^{-1}$ dry weight), leaf samples of $1 \mathrm{~cm}^{2}$ were placed in a drying oven at $60^{\circ} \mathrm{C}$ to a constant weight. All leaves and below-ground tissues of the shoots were dried at $60^{\circ} \mathrm{C}$ to a constant weight to determine their individual shoot weight.

To determine blade chlorophyll content, six replicate samples from each bed were collected and cleaned in the laboratory. Leaf tissues were extracted at $4^{\circ} \mathrm{C}$ for 2-3 days in glass tubes containing $5.0 \mathrm{~mL}$ of $\mathrm{N}, \mathrm{N}$-dimethylformamide (DMF) in the dark before spectrophotometric determination (Shimadzu UV model 2264). Absorbance was measured at 480, 647, and $664 \mathrm{~nm}$ and the absorbance at $750 \mathrm{~nm}$ was subtracted to correct for scattering due to turbidity. Pigment contents were calculated using the Wellburn (1994) extinction coefficient equations.

\section{Shoot Density, Biomass, and Production}

Shoot density inside randomly thrown quadrats or cores $(Z$. japonica, 10-cm diameter core; Z. marina and Z. caespitosa, $0.35 \times 0.35 \mathrm{~m} ; n=4-6$ ) were counted bimonthly to minimize the damage to seagrass beds and were converted to per unit area ( shoots $\mathrm{m}^{-2}$ ). Shoot biomass was calculated by multiplying shoot density by the average individual weight per shoot and was converted to per-unit-area estimates (g dry weight [DW] $\mathrm{m}^{-2}$ ). Leaf productivity was measured using a modified blademarking technique (Zieman, 1974; Kentula and McIntire, 1986). Ten to fifteen randomly chosen shoots were marked through the sheath bundle above the meristem using a hypodermic needle and they were harvested after 2-4 weeks (Park et al., 2010). Leaf materials were separated into the leaf tissues produced before and after marking, and they were then dried at $60^{\circ} \mathrm{C}$ to a constant weight. Leaf productivity per shoot (mg DW shoot ${ }^{-1} \mathrm{~d}^{-1}$ ) was determined by dividing the dry weight of the new leaf tissues produced after marking by the number of days since marking. Areal leaf productivity ( $\mathrm{g} \mathrm{DW} \mathrm{m}^{-2} \mathrm{~d}^{-1}$ ) was calculated by multiplying productivity per shoot by shoot density.

\section{Stable Isotope Analysis}

The youngest mature leaf (second or third leaf) of the shoots collected for the morphological analysis was used to assess the carbon stable isotope ratio $\left({ }^{13} \mathrm{C}\right)$ of leaf tissues. Leaf tissues were dried at $60^{\circ} \mathrm{C}$ to a constant weight and were ground using a mortar and pestle. The ground samples were wrapped in tin capsules and were analyzed to determine their carbon stable isotope ratios using an elemental analyzer (Eurovector 3000 Series; Milan, Italy) coupled with a continuous-flow isotope ratio mass spectrometer (Isoprime, GV Instruments). For carbon, Pee Dee Belemnite marine limestone (PDB) was used as the primary standard. Analytical precision was $\sim 0.1 \%$ for $\delta^{13} \mathrm{C}$.

\section{Chlorophyll a Fluorescence Measurements}

The chlorophyll $a$ fluorescence of the three seagrass species $(n=$ 10-15) were measured in situ using a pulse amplitude modulated (PAM) fluorometer (Diving-PAM, Walz) with an 8-mm optical fiber. The sampling position of the optical fiber was at the midpoint of the youngest mature leaf and the tip of the instrument's optical fiber was placed $6 \mathrm{~mm}$ from, and perpendicular to, the middle of the adaxial surface of the leaves using dark leaf clips (DLC-8). The maximum quantum yield $\left(F_{v} / F_{m}\right)$ of photosystem II (PSII) was determined after 10-min of dark-adaptation using leaf tips and was calculated using the following equation: $F_{v} / F_{m}$ $=\left(F_{m}-F_{0}\right) / F_{m}$, where $F_{0}$ is the minimal fluorescence of a darkacclimated leaf in which all PSII reaction centers are open, and $F_{m}$ is the corresponding maximum fluorescence measured with all PSII reaction centers closed following a short period $(0.8 \mathrm{~s})$ of saturating light (e.g., Van Kooten and Snel, 1990).

The rapid-light curve (RLC) was produced by the DivingPAM fluorometer under an internal program using artificial photosynthetic photon flux density (PPFD). The samples were exposed to each irradiance level $(56,115,184,268,366,537$, 721 , and $1042 \mu \mathrm{mol}$ photons $\mathrm{m}^{-2} \mathrm{~s}^{-1}$ ) at 10 -s intervals. The RLCs used a measure of relative electron transport rates (rETRs) determined from the following equation: $\operatorname{rETR}=\Delta F / F_{m}{ }^{\prime} \times$ PPFD $\times 0.5 \times 0.84$, where $\Delta F / F_{m}$ ' is the effective quantum yield of PSII, 0.84 is the assumed absorption coefficient, 0.5 is the correction for two photosystems absorbing photons, and PPFD is the programmed level of photosynthetically active radiation (PAR, 400-700 $\mathrm{nm}$ ) delivered by the halogen lamp (Genty et al., 1989; Ralph and Gademann, 2005). A standard absorption factor (0.84) was used because the best means of directly measuring absorption continues to be debated among the scientific community (Collier et al., 2008). As such, all values were considered relative ETRs (rETRs) because leaf absorptance was not directly measured (Durako et al., 2003). The RLC data were fitted to the model of Platt et al. (1981) to obtain values for photosynthetic efficiency $(\alpha)$, inhibition term $(\beta)$, minimum saturating irradiance $\left(\mathrm{E}_{\mathrm{k}}\right)$, and maximum relative electron transport rate $\left(\mathrm{rETR}_{\max }\right) . \mathrm{E}_{\mathrm{k}}$ was calculated as $\mathrm{E}_{\mathrm{k}}=\mathrm{rETR}_{\max } / \alpha$.

\section{Light-Dark Relaxation Kinetics}

To assess leaf relaxation after light exposure, the recovery of $\Delta F / F_{m}$ ' and other fluorescence parameters that were in darkness for 10-min after an RLC were measured. The RLC + recovery (LC+REC) was measured in the dark at $10 \mathrm{~s}, 30 \mathrm{~s}, 1-\mathrm{min}$, 2-min, 5-min, and 10-min after the last actinic light period of an RLC. The effective quantum yield $\left(\Delta F / F_{m}{ }^{\prime}\right)$ and nonphotochemical quenching (NPQ) parameters were calculated using the following equations: $\Delta F / F_{m}{ }^{\prime}=\left(F_{m}{ }^{\prime}-F_{t}\right) / F_{m}{ }^{\prime}$ and $N P Q=\left(F_{m}-F_{m}{ }^{\prime}\right) / F_{m}{ }^{\prime}$, respectively.

\section{Respiration Measurements}

Dark respiration of entire plants was measured using the Fibox 3 spot sensor and oxygen dipping probe (PreSens, Regensburg, Germany). Seagrass samples with rhizome and root tissues were collected in March 2008 for respiration measurements and were washed in seawater to remove sediment and epiphytes. 
Before determining the effects of temperature on respiration, the plants were allowed to equilibrate overnight to the experimental temperature. All experiments were conducted within 2 days of collection. The plants were placed in $500 \mathrm{~mL}$ of BOD (biological oxygen demand) bottles filled with $0.2-\mu \mathrm{m}$ pore sized filtered seawater equipped with magnetic stirrers. The bottles were incubated in the dark in treatment chambers at $8,16,22$, and $27^{\circ} \mathrm{C}$ (average seasonal water temperatures) for $3 \mathrm{~h}$. Next, the plants were removed from the bottles, which were stirred for 15-min to equalize the oxygen concentration in the bottles. The oxygen concentrations were measured before and after incubation for $3 \mathrm{~h}$. In the control incubations (seawater only), there were almost no changes in oxygen concentrations over the $3 \mathrm{~h}$ period. Respiration rates were normalized to the dry weight of the plant tissues in the bottles and were expressed as $\mu \mathrm{mol} \mathrm{O} \mathrm{g}^{-1} \mathrm{DW} \mathrm{h}^{-1}$.

\section{Statistical Analyses}

All values were expressed as means \pm standard error (SE). Statistical analyses were performed using SPSS ver. 18.0 (SPSS Inc., Chicago, IL). Data were tested for normality and homogeneity of variance to meet parametric test assumptions. If these assumptions were not satisfied, the data were log or squareroot transformed. Differences in light irradiance, morphological characteristics, photosynthetic pigments, shoot densities, biomasses, leaf productivity, photosynthetic characteristics, and $\delta^{13} \mathrm{C}$ values among the sampling times and species were tested for significance using a two-way analysis of variance (ANOVA), with time as a block. Dark respiration was also analyzed using a two-way ANOVA (species $\times$ water temperature). The Student-Newman-Keuls (SNK) test was used to identify statistically significant differences. Statistical significance was set to alpha $<0.05$.

\section{RESULTS}

\section{Light Irradiance and Exposure Time}

Average daily light availability showed clear seasonal variations and was significantly $(P<0.001)$ different among three zones; it was higher during boreal winter and spring than during summer and fall (Figure 2A). Average daily light irradiances at the three study zones were $\sim 40.6$ ( $\mathrm{Z}$. japonica zone), 26.5 ( $\mathrm{Z}$. marina zone), and $14.7 \mathrm{~mol}$ photons $\mathrm{m}^{-2} \mathrm{~d}^{-1}$ (Z. caespitosa zone), respectively (Figure 2A). Monthly air exposure time varied with three zones, being highest during winter-spring and being lowest during summer-fall due to seasonal tidal range, rainy season and typhoons. Zostera caespitosa meadows were never exposed to air, while Z. japonica and Z. marina were exposed to air for approximately bout 2.5 and $0.5 \mathrm{~h}$ per day, respectively (Figure 2B).

\section{Morphology and Pigments}

Shoot height, sheath length, leaf width, and specific leaf area (SLA) of the three Zostera species exhibited clear and differing seasonal variations (Figure 3). Shoot height, sheath length, and leaf width of $Z$. marina and $Z$. caespitosa increased during spring and decreased during fall, while those of $Z$. japonica were lowest

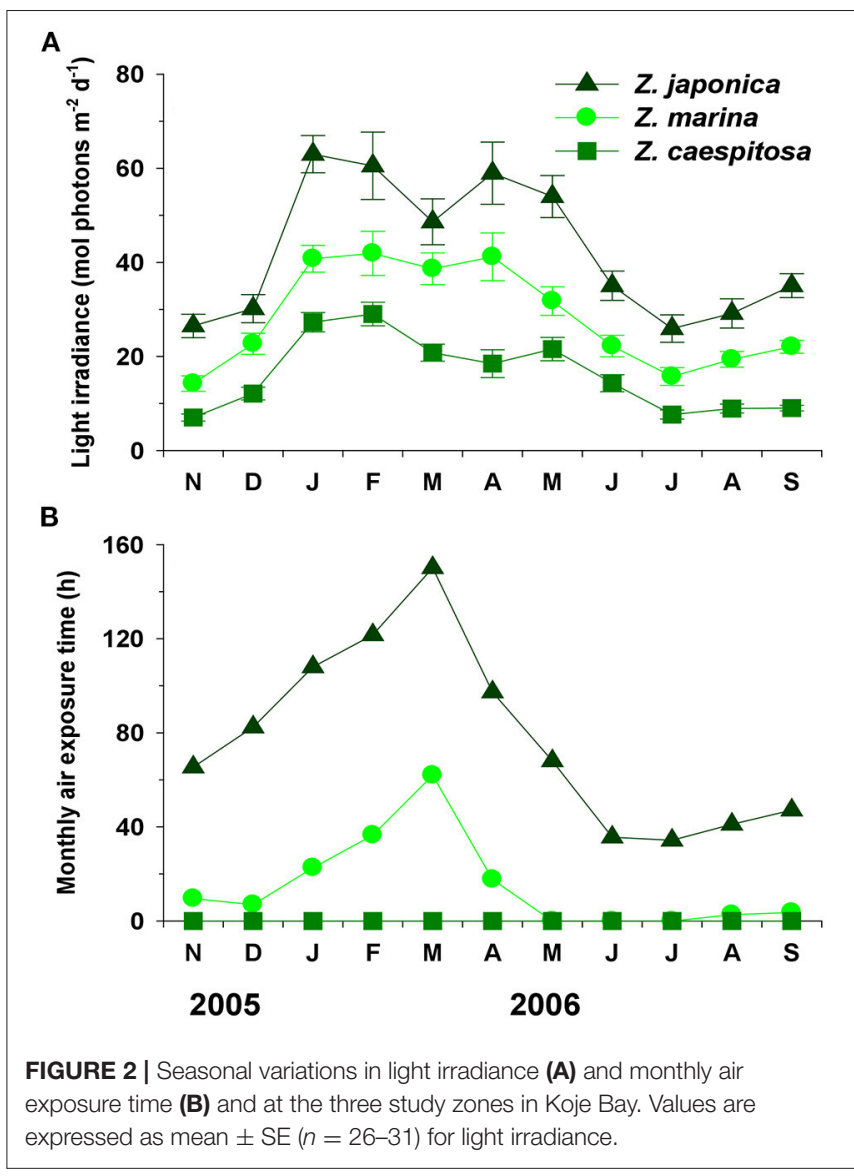

during February-April, when the duration of air exposure was longest. The SLA of the three species increased during winterspring and decreased during late spring-summer. Shoot height, sheath length, and leaf width were highest in $Z$. caespitosa and lowest in Z. japonica; however, Z. japonica showed the highest SLA and Z. caespitosa, the lowest. Zostera marina exhibited shoot height, sheath length, leaf width, and SLA values that ranged between those of the other two species.

Total chlorophyll (chl. $a+b)$ and total carotenoids contents were highest during summer-fall and lowest during springsummer (Figure 4). Zostera japonica had significantly $(P<0.001$ for both) higher total chlorophyll and total carotenoids contents than Z. marina and Z. caespitosa. The chlorophyll/carotenoids ratio varied with sampling time but did not exhibit a clear seasonal trend. The average chlorophyll/carotenoids ratio was lowest in Z. caespitosa and highest in Z. japonica and Z. marina.

\section{Shoot Density, Biomass, Productivity, and $\delta^{13} \mathrm{C}$}

Shoot density of the three species exhibited clear seasonal variations, increasing during spring and decreasing during fall and winter (Figure 5). Shoot density of $Z$. japonica (4,498 shoots $\left.\mathrm{m}^{-2}\right)$ was significantly $(P<0.001)$ higher than that of $Z$. marina $\left(1,144\right.$ shoots $\left.\mathrm{m}^{-2}\right)$ and $Z$. caespitosa $\left(95\right.$ shoots $\left.\mathrm{m}^{-2}\right)$. The total biomass of the species showed seasonal trends similar to those 

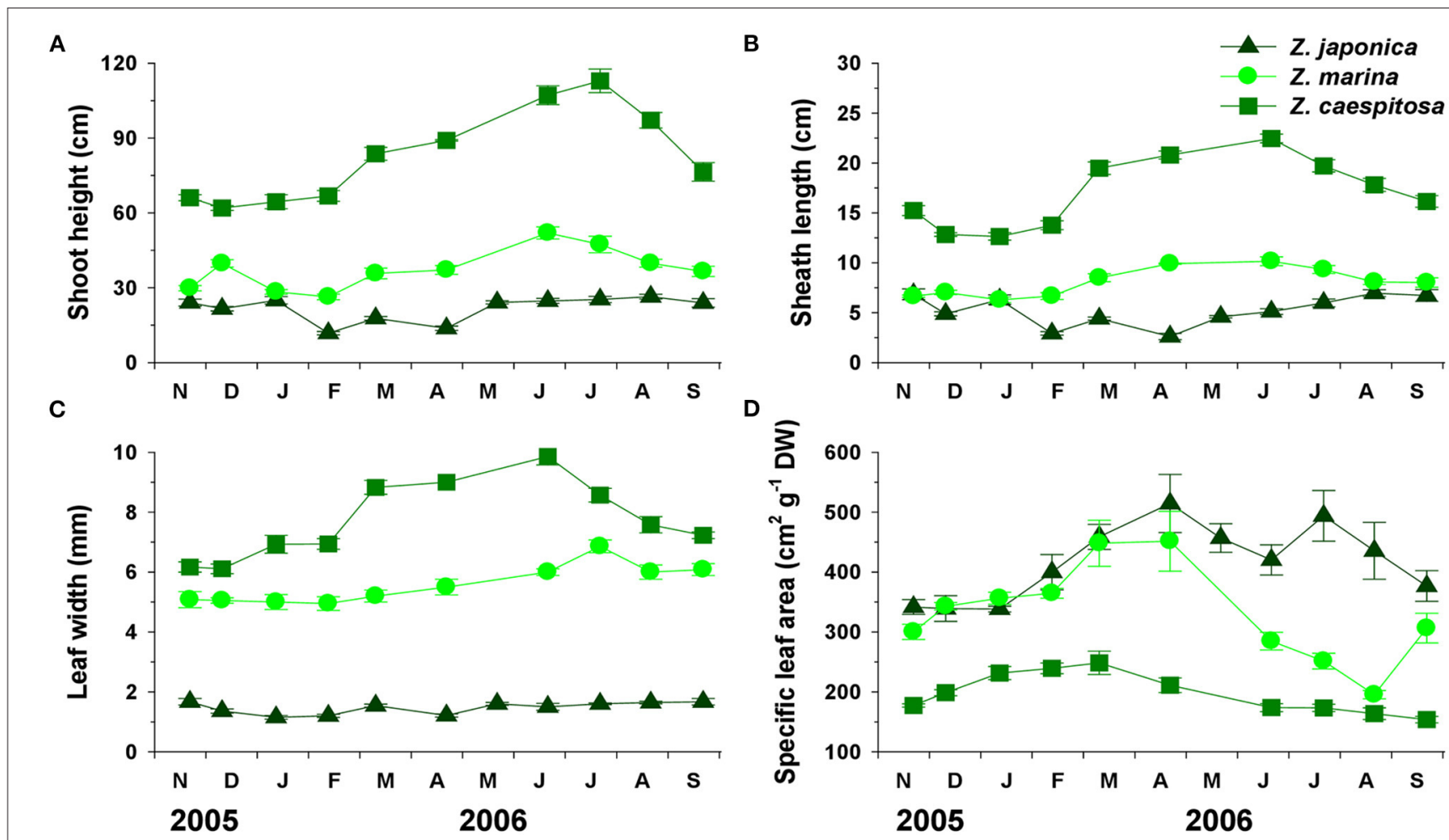

FIGURE 3 | Three Zostera species (Z. japonica, Z. marina, and Z. caespitosa). Seasonal changes in shoot height (A), sheath length (B), leaf width (C), and specific leaf area (D) in Koje Bay. Values are expressed as mean \pm SE $(n=10-15)$.

of shoot density and was significantly $(P<0.001)$ higher in $Z$. marina $\left(393 \pm 55 \mathrm{~g} \mathrm{DW} \mathrm{m}^{-2}\right)$ than in $Z$. japonica $(123 \pm 26 \mathrm{~g}$ $\left.\mathrm{DW} \mathrm{m}^{-2}\right)$ and $Z$. caespitosa $\left(121 \pm 21 \mathrm{~g} \mathrm{DW} \mathrm{m}^{-2}\right)$ (Figure 5).

Leaf productivity per shoot and areal leaf productivity also exhibited clear seasonal variations, increasing during spring and decreasing during summer and early fall (Figure 6). Zostera caespitosa showed significantly $(P<0.001)$ higher leaf productivity per shoot than $Z$. japonica and $Z$. marina. In contrast, $Z$. marina showed the highest in areal leaf productivity. The average areal leaf productivity values of $Z$. marina, $Z$. japonica, and $Z$. caespitosa were $5.4 \pm 2.1,1.4 \pm 0.4$, and $1.0 \pm$ $0.4 \mathrm{~g} \mathrm{DW} \mathrm{m}^{-2} \mathrm{~d}^{-1}$, respectively.

The $\delta^{13} \mathrm{C}$ values significantly $(P<0.001)$ varied with species and were dependent on their depth (Figure 7). The $\delta^{13} \mathrm{C}$ values of both Z. japonica and Z. marina peaked in March and decreased in late spring, while those of $Z$. caespitosa were relatively constant during the experimental period, except in July. The average $\delta^{13} \mathrm{C}$ values were significantly $(P<0.001)$ more negative in $Z$. japonica $(-10.41 \pm 0.42 \%$ o $)$ than in $Z$. marina $(-9.33 \pm 0.34 \%$ o $)$ and $Z$. caespitosa $(-7.57 \pm 0.27 \%$ o $)$.

\section{Fluorescence Parameters and Dark Respiration}

Significant seasonal differences $(P<0.001)$ in $\mathrm{rETR}_{\max }$ were observed for Z. japonica and Z. marina, which were highest in January and lowest in July and September, while those of Z. caespitosa were relatively constant (Figure 8A). The average
rETR $_{\max }$ values of $Z$. marina, $Z$. japonica, and $Z$. caespitosa were $17.1 \pm 1.6,13.8 \pm 1.1$, and $11.5 \pm 0.4 \mu \mathrm{mol}$ electrons $\mathrm{m}^{-2} \mathrm{~s}^{-1}$, respectively. The $F_{v} / F_{m}$ and photosynthetic efficiency $(\alpha)$ of the three species exhibited distinct seasonal variations, increasing during winter and spring and decreasing during summer and fall (Figures 8B,C). The $F_{v} / F_{m}$ was highest in $Z$. caespitosa and lowest in $Z$. japonica. The photosynthetic efficiency $(\alpha)$ of $Z$. japonica was significantly $(P<0.001)$ lower than that of the other two species. The minimum saturating irradiance $\left(\mathrm{E}_{\mathrm{k}}\right)$ also showed significant $(P<0.001)$ seasonal variations, but with the inverse trend (Figure 8D). Zostera japonica showed the highest $\mathrm{E}_{\mathrm{k}}$ and was significantly different $(P<0.001)$ from that of the other two species.

During the course of the RLC, the NPQ of Z. japonica was two- to three-fold higher than that of $Z$. marina and $Z$. caespitosa (Figure 9). The relative relaxation proportion of $Z$. japonica (56\%) was lower than that of Z. marina (78\%) and Z. caespitosa $(71 \%)$ during the first $30 \mathrm{~s}$. However, the relative relaxation proportion of $Z$. japonica (98\%) was significantly $(P<0.001)$ lower than that of $Z$. marina (93\%) and $Z$. caespitosa (87\%) after 2 -min. The NPQ of $Z$. japonica was completely extinguished after 5 -min (100\%) in the dark. In contrast, even after 10-min of darkness, around 1.4 and 5\% of NPQ remained in Z. marina and $Z$. caespitosa leaves, respectively.

Dark respiration in the three species varied significantly $(P$ $<0.001$ ) with water temperature (Table 1). The average dark respiration of $Z$. japonica was significantly $(P<0.001)$ higher 


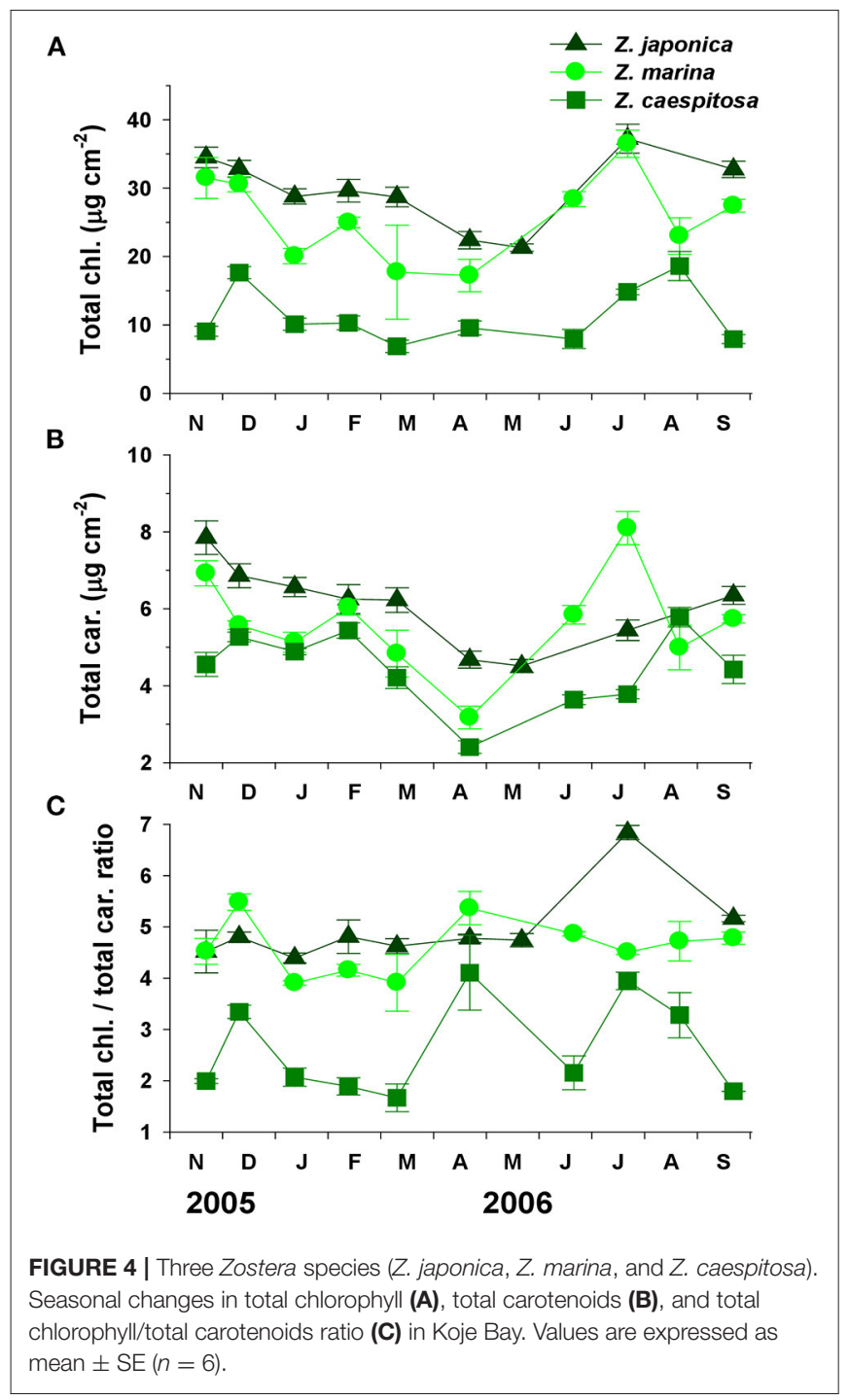

than that of Z. marina and Z. caespitosa (Table 1). Additionally, the dark respiration of the three species increased significantly with increasing water temperature $(P<0.001$ in species $\times$ water temperature interaction), which was highest at $27^{\circ} \mathrm{C}$ and lowest at $8^{\circ} \mathrm{C}$.

\section{DISCUSSION}

We found interspecific variations in the morphological and photosynthetic characteristics of three Zostera species associated with vertical zonation patterns. Subtidal $Z$. caespitosa was the tallest of the three species and had wider leaves, while $Z$. japonica in the upper intertidal zone was the shortest and had the thickest and narrowest leaves. The morphological responses of seagrasses to reduced light availability with increasing depth have been widely reported (Olesen et al., 2002; Collier et al., 2007; Mackey et al., 2007; Kohlmeier et al., 2014). In shading experiments with $Z$. capricorni, shoots exposed to high light

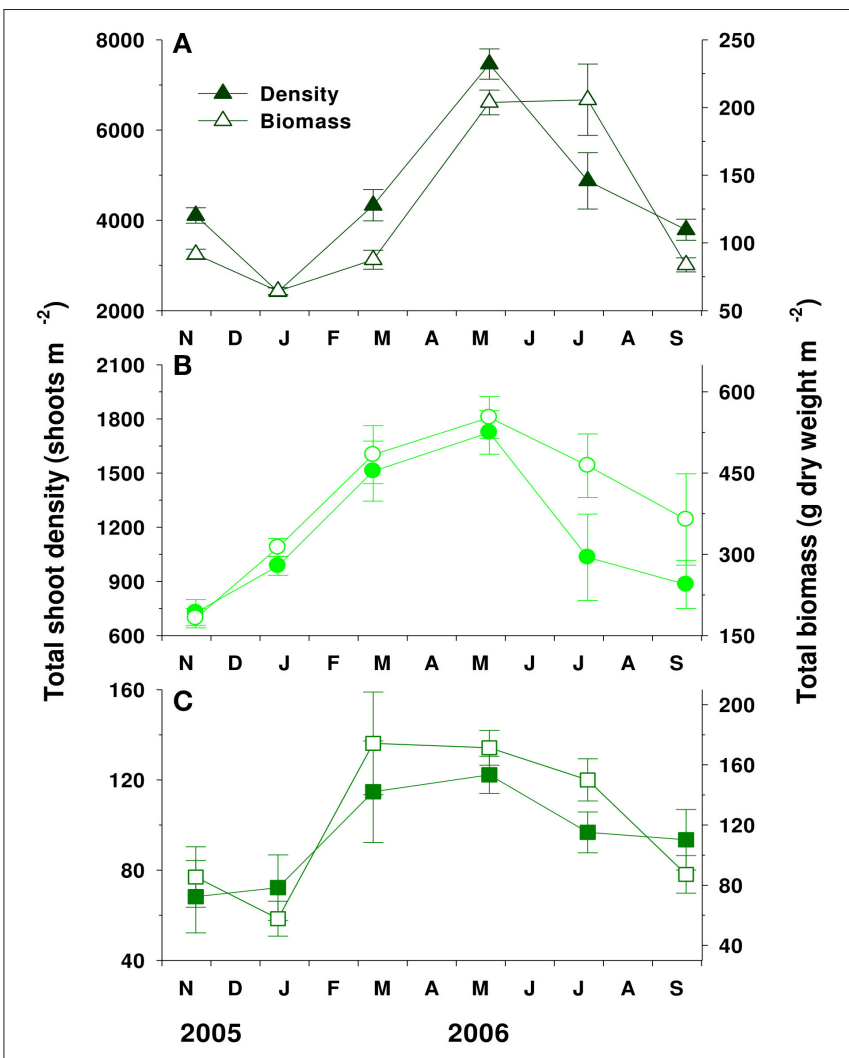

FIGURE 5 | Seasonal variations in the total shoot density and total biomass of Zostera japonica (A), Zostera marina (B), and Zostera caespitosa (C) in Koje Bay. Values are expressed as mean \pm SE $(n=4-6)$.

irradiance were shorter than those exposed to low light irradiance (Abal et al., 1994). Subtidal seagrasses enlarge their shoots or produce longer and wider leaves to capture photons under lowlight conditions (Watanabe et al., 2005; de los Santos et al., 2010). Enríquez and Pantoja-Reyes (2005) reported that leaf morphology (leaf thickness or specific leaf area) is related to the depth-induced reductions in surface irradiance. This shows that light availability influences morphological variations (leaf length and width) in seagrasses and may be the main factors regulating the vertical zonation of seagrasses. Seagrasses have the ability to photo-acclimate by altering and optimizing photosynthetic pigment content in response to light availability (Enríquez, 2005; Ralph et al., 2007). With increasing depth or decreasing light irradiance, leaf chlorophyll $a+b$ content usually increases, while UV absorbance and total carotenoids content typically decreases (Longstaff and Dennison, 1999; Olesen et al., 2002; Park et al., 2016). However, the opposite effect occurs under low-light conditions (Biber et al., 2009; Collier et al., 2012; Kohlmeier et al., 2014). In the present study, chlorophyll and total carotenoids contents, and the chlorophyll/carotenoids ratio of three Zostera species corresponded to ambient light availability. Zostera japonica exposed to more light during low tide had the highest carotenoids content and subtidal $Z$. caespitosa had a relatively low carotenoids content throughout. Carotenoids lose 


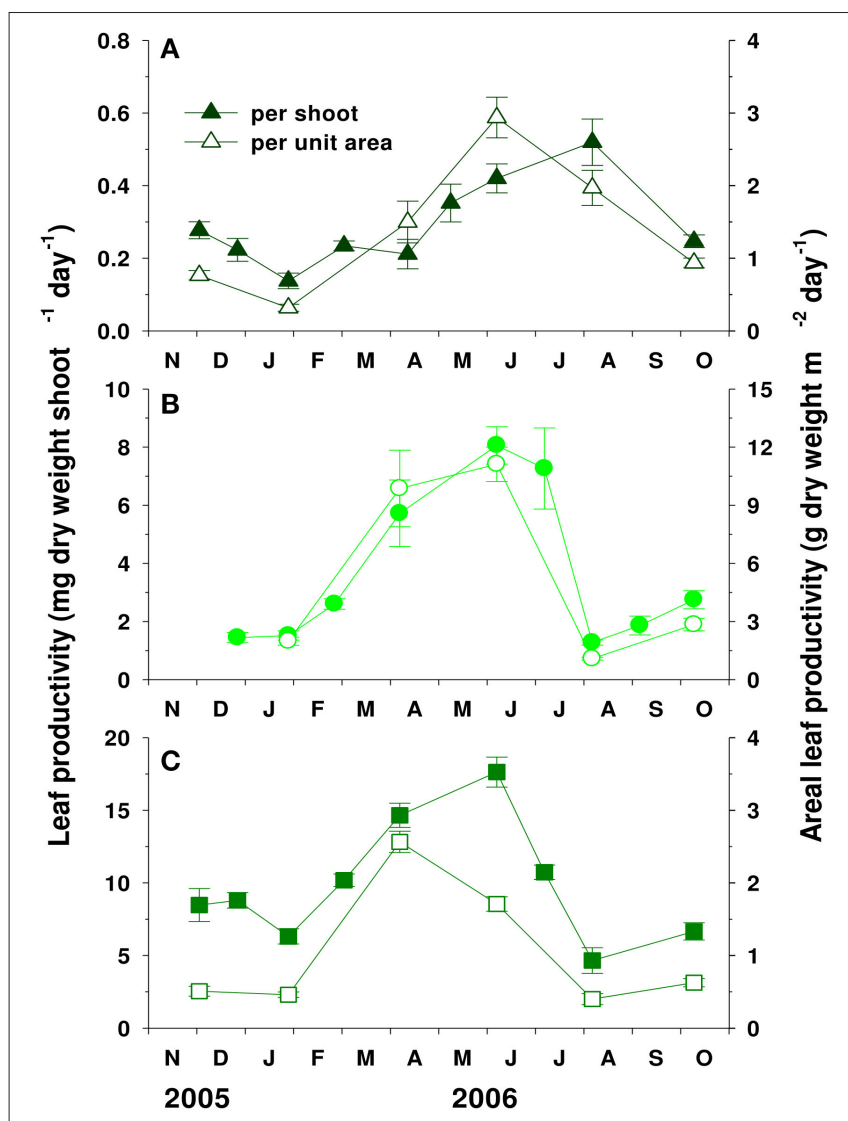

FIGURE 6 | Seasonal variations in leaf productivity per shoot and per unit area of Zostera japonica (A), Zostera marina (B), and Zostera caespitosa (C) in Koje Bay. Values are expressed as mean \pm SE $(n=6-10)$.

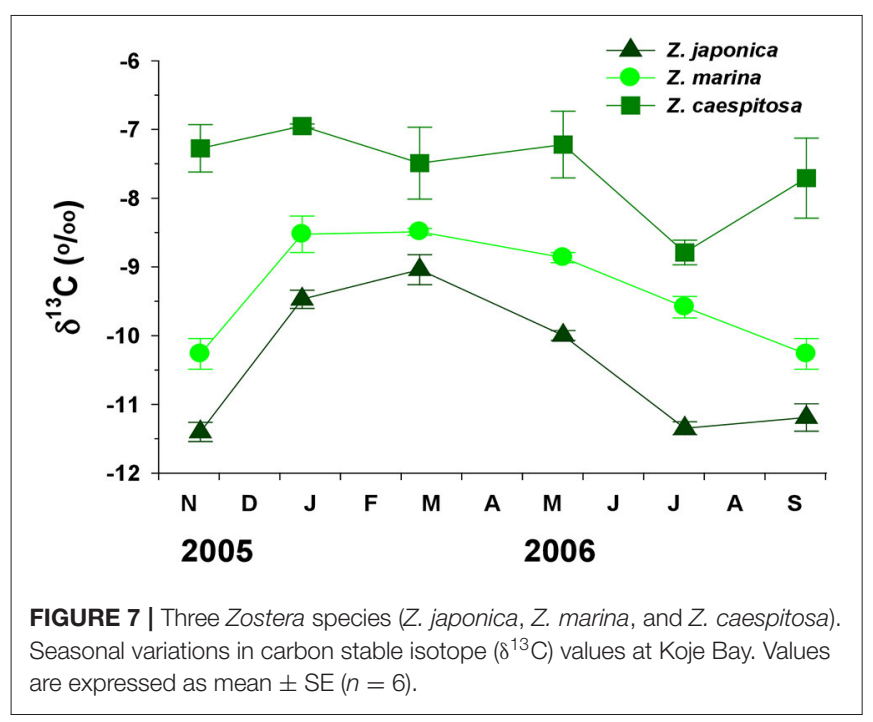

excitation energy through heat, which protects photosystems or chlorophyll from excess light (Amstrong and Hearst, 1996; Demmig-Adams and Adams, 1996) and intertidal Z. marina populations have higher carotenoids contents than subtidal populations to avoid photodamage due to excess light during the day (Park et al., 2016). When plants are exposed to high light irradiances, their total carotenoids content increases (Härtel and Grimm, 1998; Ralph et al., 2002). Therefore, the observed differences in pigment content appear to be an important acclimation strategy across all three species enabling them to cope with gradients in light conditions occurring along the depth zonation.

Seagrass vertical zonation patterns can be explained by mechanisms at the population and meadow level and by physiological characteristics at the individual level (Tanaka and Nakaoka, 2004; Shafer et al., 2007). Subtropical seagrasses mitigate desiccation stress by allowing their leaves to lie atop moist sediment (Björk et al., 1999; Tanaka and Nakaoka, 2004) and the high shoot density of intertidal seagrass can reduce desiccation stress through shading and overlapping leaves (Tanaka and Nakaoka, 2004; Shafer et al., 2007). Although the effective quantum yield of $Z$. japonica at the individual level was more affected by desiccation than that of $Z$. marina, the effective quantum yield of the densely overlapping leaves of $Z$. japonica was significantly higher than that of $Z$. marina with air exposure (Kim et al., 2020). In this study, Z. japonica may have been weakly affected by desiccation stress during exposure at low tide, possibly because its structural flexibility and high shoot density allows leaves to contact moist sediment and reduce water loss. This indicates that growth strategies should be considered when evaluating seagrass desiccation tolerance.

The $\mathrm{rETR}_{\max }$ and $F_{v} / F_{m}$ values from the RLCs indicated physiological differences and acclimation along the depth-related light gradient. Subtidal Z. caespitosa had low photosynthetic activity, while $Z$. japonica and Z. marina exposed to air at low tide had high photosynthetic activity. However, the rETR $\mathrm{max}_{\max }$ of $Z$. japonica was lower than that of $Z$. marina even though the exposure time of $Z$. japonica was two-fold that of $Z$. marina. Prolonged exposure to high irradiance may reduce $F_{v} / F_{m}$ in marine plants (Yakovleva and Titlyanov, 2001; Durako and Kunzelman, 2002; Manassa et al., 2017). Zostera caespitosa that were not exposed to air showed a high $F_{v} / F_{m}$ value, which is consistent with past reports of increase in leaf fluorescence ratios in response to decreased light irradiance in seagrass (Dawson and Dennison, 1996; Major and Dunton, 2002). The photosynthetic efficiency $(\alpha)$ and $E_{k}$ values of the three species also showed consistent patterns with depth. Zostera japonica had low $\alpha$ and high $\mathrm{E}_{\mathrm{k}}$ values, while $Z$. caespitosa showed the reverse trend. Zostera marina had intermediate $\alpha$ and $\mathrm{E}_{\mathrm{k}}$ values. This was similar to seagrass zonation patterns, suggesting successful adaption to environmental conditions.

The NPQ can be divided into three processes based on the time required to relax after exposure to high-light conditions. The NPQ components that relax within a range of seconds to minutes are associated with the removal of energy-dependent NPQ (qE) and state-transition NPQ (qT), whereas slower relaxation $(>10$ min to several hours) is associated with photoinhibition (qI) and changes in energy distribution in favor of PSII (Horton and Hague, 1988; White and Critchley, 1999). LC+REC helps distinguish the relaxation kinetics of the NPQ components (Ralph and Gademann, 2005). Although the NPQ of $Z$. 


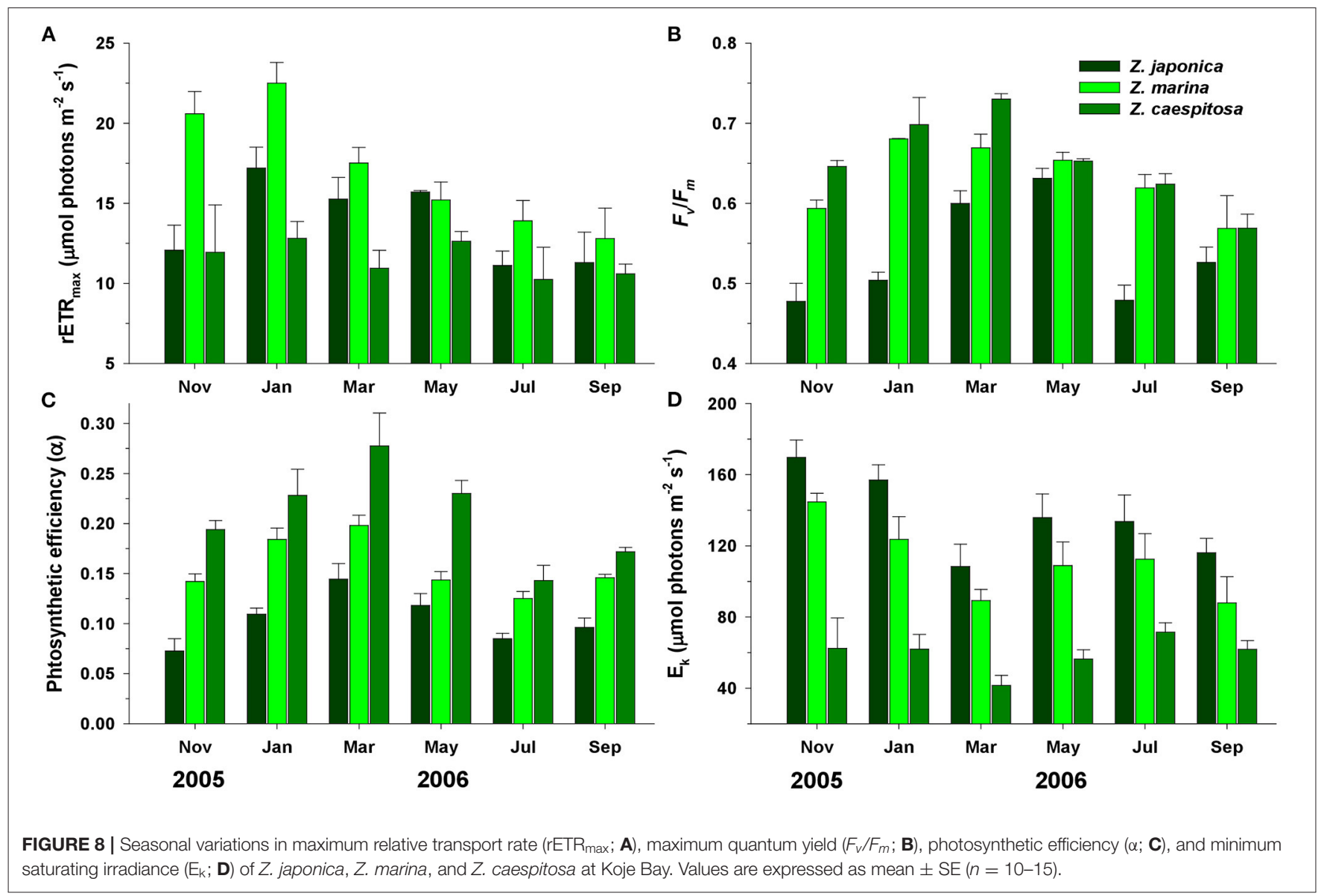

caespitosa was mostly relaxed, $\sim 5 \%$ of the NPQ remained in $Z$. caespitosa leaves after 10-min of darkness. This is likely to be photoinhibitory quenching (qI). However, the NPQ of $Z$. japonica was energy-dependent quenching ( $\mathrm{qE}$ ), as it was mostly relaxed after 2-min and completely extinguished after 5-min. This results was similar to that of Ralph and Gademann (2005), who reported that The NPQ in high-light adapted seagrass leaf completely extinguished after 5 -min. This suggests that $Z$. japonica may be a high-light adapted species, while $Z$. caespitosa may be a low-light adapted species. Shallow-water seagrasses have a higher capacity for light protection and NPQ compared to deep-water seagrasses (Ralph et al., 1998).

Seagrass respiration is primarily influenced by temperature and depth (reviewed by Touchette and Burkholder, 2000). Respiration rates continue to increase with increasing temperatures (Bulthuis, 1983; Marsh et al., 1986; Pedersen et al., 2016). Dark respiration of Z. marina and Thalassia testudinum was lowest in winter, increased with increasing water temperature in spring and peaked in summer (reviewed by Lee et al., 2007). The respiration rate of $Z$. marina at $5.5 \mathrm{~m}$ was $40 \%$ lower than that at $1.3 \mathrm{~m}$ (Dennison and Alberte, 1982). To prevent anaerobic respiration in below-ground tissues, many aquatic plants (including seagrasses) translocate and release $\mathrm{O}_{2}$ in the rhizosphere during active photosynthesis
(Sand-Jensen et al., 1982; Smith et al., 1984; Caffrey and Kemp, 1991). Therefore, seagrasses with high below-ground biomasses have high respiratory demand (Tanaka and Nakaoka, 2007). In this study, dark respiration increased with increasing water temperature, and subtidal Z. caespitosa showed the lowest respiration rate. Additionally, $Z$. caespitosa had the lowest below-/above-ground biomass (data not shown), which may have affected its respiration rate. These results suggest that $Z$. caespitosa has the potential to grow in the subtidal zone despite its low photosynthetic activity.

Seagrass $\delta^{13} \mathrm{C}$ values significantly correlate with seagrass production rates (Cooper and DeNiro, 1989; Hemminga and Mateo, 1996). Most seagrasses use $\mathrm{HCO}_{3}^{-}$for photosynthetic carbon reduction, which is the most abundant form of dissolved inorganic carbon in seawater and has a less negative $\delta^{13} \mathrm{C}$ value than dissolved $\mathrm{CO}_{2}$ due to a low supply of $\mathrm{CO}_{2}$ in seawater (Hemminga and Mateo, 1996; Beer and Rehnberg, 1997; Invers et al., 2001). Therefore, seagrass $\delta^{13} \mathrm{C}$ values increase during high productivity periods by utilizing $\mathrm{HCO}_{3}^{-}$with a less negative $\delta^{13} \mathrm{C}$ value than dissolved $\mathrm{CO}_{2}$ due to reduced carbon discrimination (Kim et al., 2014). Additionally, the ${ }^{13} \mathrm{C}$ values become more negative with less light due to a reduced photosynthetic and production demand for carbon, allowing more carbon discrimination (Cooper and DeNiro, 1989; 


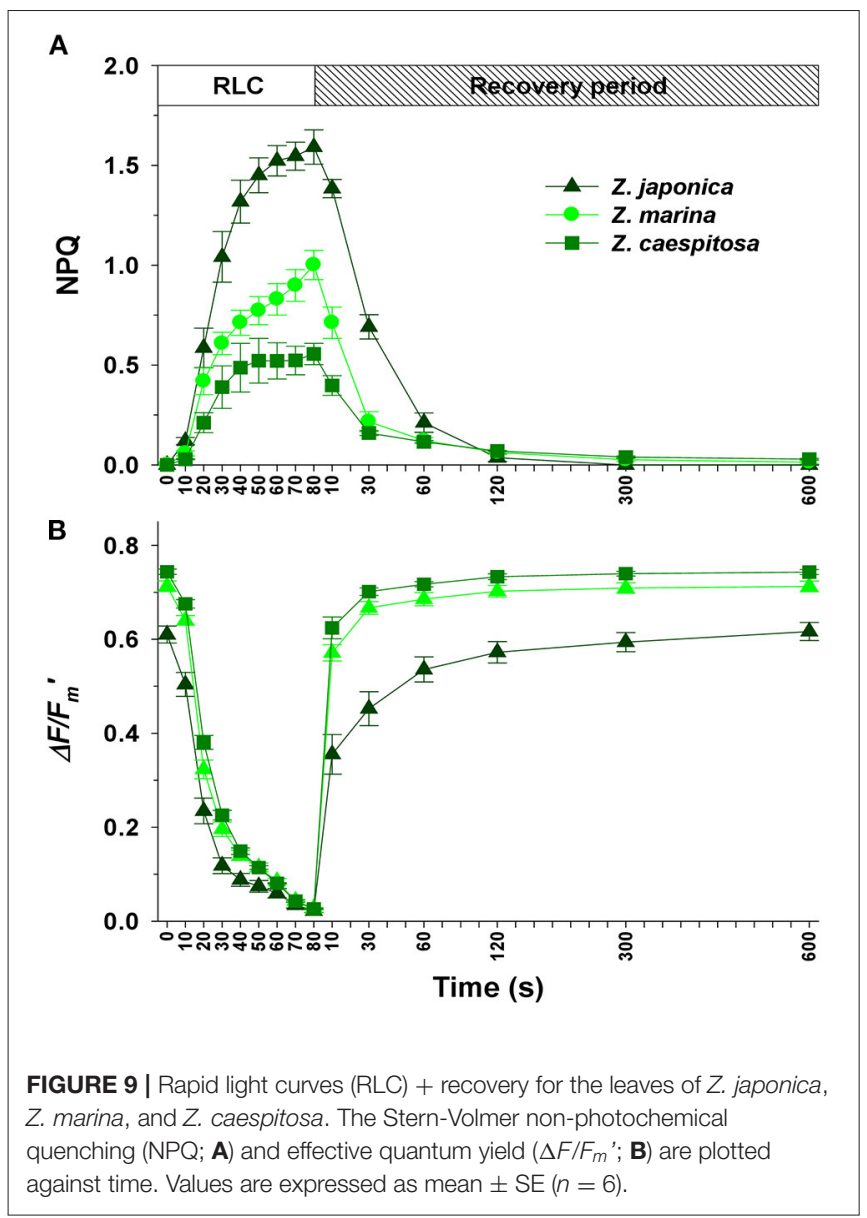

Abal et al., 1994; Hemminga and Mateo, 1996). Contrastingly, the reduced photosynthetic discrimination against the heavier isotope may result in increased $\delta^{13} \mathrm{C}$ values due to photosynthetic carbon limitation during periods of high light (Fourqurean et al., 2005; Campbell and Fourqurean, 2009). In this study, however, an increase in $\delta^{13} \mathrm{C}$ values was not observed during high productivity periods. The $\delta^{13} \mathrm{C}$ values were highest in $Z$. caespitosa and lowest in $Z$. japonica, regardless of light irradiance. The productivity $-{ }^{13} \mathrm{C}$ relationship was not observed in the shallow seagrass meadows as carbon isotopic discrimination in seagrass saturates earlier than productivity with increasing light irradiance (Mateo et al., 2001). During the experiment, the $\delta^{13} \mathrm{C}$ values were not controlled by the light irradiance in each zone, which suggests that $\delta^{13} \mathrm{C}$ values are not determined by productivity and light conditions.

Seagrass $\delta^{13} \mathrm{C}$ values are mainly determined by inorganic carbon sources (i.e., $\mathrm{HCO}_{3}^{-}$or dissolved $\mathrm{CO}_{2}$ ) and availability during photosynthesis (Raven et al., 2002; Lepoint et al., 2003). They are also controlled by atmospheric $\mathrm{CO}_{2}$ use and inorganic carbon concentrating mechanisms, such as $\mathrm{CO}_{2}$ diffusion, active $\mathrm{CO}_{2}$ transport and active $\mathrm{HCO}_{3}^{-}$influx under different environmental conditions (Raven et al., 2002). The heavier $\delta^{13} \mathrm{C}$ values of tropical seagrass are attributed to the use of $\mathrm{HCO}_{3}^{-}$ due to a low supply of $\mathrm{CO}_{2}$ in seawater (Hemminga and Mateo,
TABLE 1 | Whole-plant dark respiration rates of the three Zostera species at four water temperatures.

\begin{tabular}{|c|c|c|c|c|}
\hline \multirow[t]{2}{*}{ Species } & \multicolumn{4}{|c|}{ Dark respiration $\left(\mu \mathrm{mol} \mathrm{O}_{2} \mathrm{~g}^{-1}\right.$ dry weight $\left.\mathrm{h}^{-1}\right)$} \\
\hline & $8^{\circ} \mathrm{C}$ & $16^{\circ} \mathrm{C}$ & $22^{\circ} \mathrm{C}$ & $27^{\circ} \mathrm{C}$ \\
\hline Zostera japonica & $53.3 \pm 2.7^{\mathrm{a}}$ & $77.4 \pm 6.4^{\mathrm{b}}$ & $87.0 \pm 3.6^{b}$ & $105.3 \pm 4.4^{c}$ \\
\hline Zostera marina & $12.1 \pm 0.1^{\mathrm{a}}$ & $17.6 \pm 0.6^{a}$ & $29.2 \pm 2.5^{b}$ & $39.5 \pm 3.8^{c}$ \\
\hline Zostera caespitosa & $7.2 \pm 0.7^{\mathrm{a}}$ & $11.2 \pm 0.1^{b}$ & $13.1 \pm 1.0^{\mathrm{bc}}$ & $16.3 \pm 1.6^{d}$ \\
\hline
\end{tabular}

Water temperature is the seasonal average. Values are expressed as means $\pm S E(n=$ 8). Values with the same letter are not significantly different among water temperature treatments $(P<0.05)$.

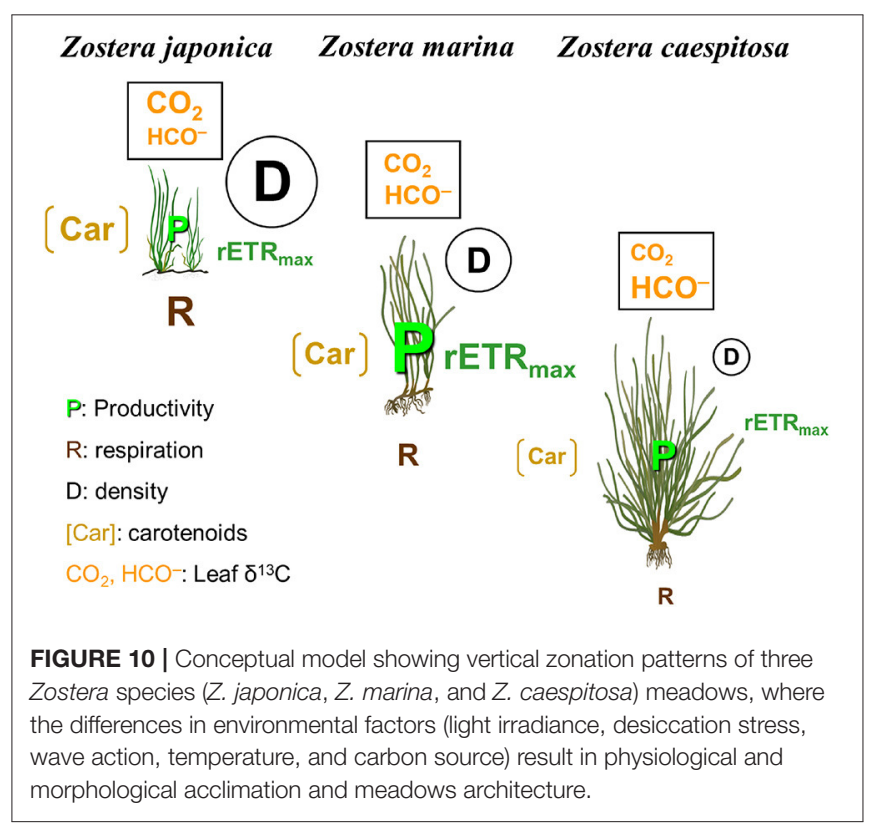

1996). The lighter $\delta^{13} \mathrm{C}$ of Halophila ovalis leaves suggests that $\mathrm{CO}_{2}$ was so abundant that $H$. ovalis did not take up $\mathrm{HCO}_{3}^{-}$ in the seawater (Yamamuro et al., 2001). Our results showed that the $\delta^{13} \mathrm{C}$ values of the species were consistent with their zonation patterns. For photosynthesis, subtidal Z. caespitosa may have absorbed inorganic carbon from the water column via active $\mathrm{CO}_{2}$ transport and $\mathrm{HCO}_{3}^{-}$influx, resulting in higher $\delta^{13} \mathrm{C}$ values. However, the lighter $\delta^{13} \mathrm{C}$ values of intertidal $Z$. japonica may have resulted from atmospheric $\mathrm{CO}_{2}$ use or a sufficient $\mathrm{CO}_{2}$ supply in seawater due to air mixing during tidal changes (Kim et al., 2016b). Contrastingly, the values of $Z$. marina may have been influenced by both processes. Thus, these results suggest that three Zostera species utilize different inorganic carbon sources and carbon concentrating mechanisms for photosynthesis to co-exist or avoid resource competition.

\section{CONCLUSION}

Although environmental conditions were perhaps different in this study area, these conclusions are still supported for data collected 15 years ago and providing support for the 
mismatch between the respiration data measured in seagrasses 3 years after other measurements. In this study, these results strongly support our hypothesis, namely, that morphological and physiological characteristics and meadows architecture of three Zostera species strongly reflected vertical zonation patternsrelated environmental stressors (Figure 10). The photosynthetic activities suggest that $Z$. japonica is a high-light adapted species and $Z$. caespitosa is a low-light adapted one, while $Z$. marina shows high plasticity of growth and physiology to allow this species to occur in the intertidal and subtidal zones (Figure 10). If global climate change and its effects are accelerating over time, this change could lead to increasing space competition among seagrass. Tidal inundation and reduced light availability caused by sea level rise may facilitate the penetration of subtidal species into middle and lower intertidal zones. In contrast, these factors appear to limit expansion of intertidal seagrass species meadows lower boundary to the middle and lower intertidal zones. The distribution of intertidal seagrass species may be shifted upper in the intertidal zone.

However, seagrasses vary in their sensitivity to changes in environmental conditions such as light reduction and temperature; for example, Halophila species occurs in both highand low-light regions, while Thalassia and Cymodocea species are found only in high-light area (Carruthers et al., 2002). Under such circumstances, Thalassia and Cymodocea species is expected to shift upper intertidal zone to achieve optimum lighting conditions. Thus, a better understanding how seagrass species respond to environmental changes, which are being exacerbated by climate change, will provide valuable information

\section{REFERENCES}

Abal, E. G., Loneragan, N., Bowen, P., Perry, C. J., Udy, J. W., and Dennison, W. C. (1994). Physiological and morphological responses of the seagrass Zostera capricorni Aschers, to light intensity. J. Exp. Mar. Biol. Ecol. 178, 113-129. doi: 10.1016/0022-0981(94)90228-3

Aioi, K., and Nakaoka, M. (2003). “The seagrass of Japan," in World Atlas of Seagrasses, eds E. P. Green and F. T. Short (Berkeley, CA: University of California Press), 185-192.

Amstrong, G. A., and Hearst, J. E. (1996). Carotenoids 2: genetics and molecular biology of carotenoid pigment biosynthesis. FASEB J. 10, 228-237. doi: 10.1096/fasebj.10.2.8641556

Apichanangkool, P., and Prathep, A. (2014). Changes in seagrass leaf reddening and morphology in response to emersion. Bot. Mar. 57, 433-440. doi: 10.1515/bot-2014-0004

Beck, M. W., Heck, K. L., Able, K. W., Childers, D. L., Eggleston, D. B., Gillanders, B. M., et al. (2001). The identification, conservation, and management of estuarine and marine nurseries for fish and invertebrates. Bioscience 51, 633-641. doi: 10.1641/0006-3568(2001)051[0633:TICAMO]2.0.CO;2

Beer, S., and Rehnberg, J. (1997). The acquisition of inorganic carbon by the seagrass Zostera marina. Aquat. Bot. 56, 277-283. doi: 10.1016/S0304-3770(96)01109-6

Biber, P. D., Kenworthy, W. J., and Paerl, H. W. (2009). Experimental analysis of the response and recovery of Zostera marina (L.) and Halodule wrightii (Ascher.) to repeated light-limitation stress. J. Exp. Mar. Biol. Ecol. 369, 110-117. doi: 10.1016/j.jembe.2008.10.031

Björk, M., Uku, J., Weil, A., and Beer, S. (1999). Photosynthetic tolerances to desiccation of tropical intertidal seagrasses. Mar. Ecol. Prog. Ser. 191, 121-126. doi: $10.3354 /$ meps 191121 for predicting their vertical zonation patterns and designing effective management strategies for seagrass restoration.

\section{DATA AVAILABILITY STATEMENT}

The raw data supporting the conclusions of this article will be made available by the authors, without undue reservation.

\section{AUTHOR CONTRIBUTIONS}

SP and K-SL analyzed the data and wrote the draft. KM and SK conducted the fieldwork and analyzed the data. All authors generated the hypotheses, designed the study, helped improve the manuscript, and approved the submission.

\section{FUNDING}

This study was supported by the Basic Science Research Program through the National Research Foundation of Korea (NRF) funded by the Ministry of Education (2019R1A6A1A10072987) and (2019R111A2A01040865). This project also was supported by the project entitled Long-term change of structure and function in marine ecosystems of Korea funded by the Ministry of Oceans and Fisheries, Korea.

\section{ACKNOWLEDGMENTS}

We would like to thank Y. K. Kim and J. H. Kim for their countless hours of field and lab assistance.

Boese, B. L., Robbins, B. D., and Thursby, G. (2005). Desiccation is a limiting factor for eelgrass (Zostera marina L.) distribution in the intertidal zone of a northeastern Pacific (USA) estuary. Bot. Mar. 48, 274-283. doi: 10.1515/BOT.2005.037

Brierley, A. S., and Kingsford, M. J. (2009). Impacts of climate change on marine organisms and ecosystems. Curr. Biol. 19, R602-R614. doi: 10.1016/j.cub.2009.05.046

Bulthuis, D. A. (1983). Effects of temperature on the photosynthesis-irradiance curve of the Australian seagrass, Heterozostera tasmanica. Mar. Biol. Lett. $4,47-58$

Cabaço, S., Machás, R., and Santos, R. (2009). Individual and population plasticity of the seagrass Zostera noltii along a vertical intertidal gradient. Estuar. Coast. Shelf Sci. 82, 301-308. doi: 10.1016/j.ecss.2009.01.020

Caffrey, J. M., and Kemp, W. M. (1991). Seasonal and spatial patterns of oxygen production, respiration, and root-rhizome release in Potamogeton perfoliatus L. and Zostera marina L. Aquat Bot. 40, 109-128. doi: 10.1016/0304-3770(91)90090-R

Campbell, J. E., and Fourqurean, J. W. (2009). Interspecific variation in the elemental and stable isotope content of seagrasses in South Florida. Mar. Ecol. Prog. Ser. 387, 109-123. doi: 10.3354/meps08093

Carruthers, T. J. B., Dennison, W. C., Longstaff, B. J., Waycott, M., Abal, E. G., McKenzie, L. J., et al. (2002). Seagrass habitats of northeast Australia: models of key processes and controls. Bull. Mar. Sci. 71, 1153-1169.

Collier, C. J., Lavery, P. S., Masini, R. J., and Ralph, P. J. (2007). Morphological, growth, and meadow characteristics of the seagrass Posidonia sinuosa along a depth-related gradient of light availability. Mar. Ecol. Prog. Ser. 337, 103-115. doi: 10.3354/meps337103

Collier, C. J., Lavery, P. S., Ralph, P. J., and Masini, R. J. (2008). Physiological characteristics of the seagrass Posidonia sinuosa along a depth-related gradient 
of light availability. Mar. Ecol. Prog. Ser. 353, 65-79. doi: 10.3354/meps 07171

Collier, C. J., Waycott, M., and Ospina, A. G. (2012). Responses of four IndoWest Pacific seagrass species to shading. Mar. Pollut. Bull. 65, 342-354. doi: 10.1016/j.marpolbul.2011.06.017

Cooper, L. W., and DeNiro, M. J. (1989). Stable carbon isotope variability in the seagrass Posidonia oceanica: evidence for light intensity effects. Mar. Ecol. Prog. Ser.50, 225-229. doi: 10.3354/meps050225

Dawson, S. P., and Dennison, W. C. (1996). Effects of ultraviolet and photosynthetically active radiation on five seagrass species. Mar. Biol. 125, 629-638. doi: 10.1007/BF00349244

de los Santos, C. B., Brun, F. G., Bouma, T. J., Vergara, J. J., and Pérez-Lloréns, J. L. (2010). Acclimation of seagrass Zostera noltii to co-occurring hydrodynamic and light stresses. Mar. Ecol. Prog. Ser. 398, 127-135. doi: 10.3354/meps08343

Demmig-Adams, B., and Adams, W. W. III (1996). The role of xanthophyll cycle carotenoids in the protection of photosynthesis. Trends Plant. Sci. 1, 21-26. doi: 10.1016/S1360-1385(96)80019-7

Dennison, W. C., and Alberte, R. S. (1982). Photosynthetic responses of Zostera marina L. (eelgrass) to in situ manipulations of light intensity. Oecologia 55, 137-144. doi: 10.1007/BF00384478

Duarte, B., Martins, I., Rosa, R., Matos, A. R., Roleda, M. Y., Reusch, T. B. H., et al. (2018). Climate change impacts on seagrass meadows and macroalgal forests: an integrative perspective on acclimation and adaptation potential. Front. Mar. Sci. 5:190. doi: 10.3389/fmars.2018.00190

Duarte, C. M. (1991). Seagrass depth limits. Aquat. Bot. 40, 363-377. doi: 10.1016/0304-3770(91)90081-F

Durako, M. J., and Kunzelman, J. I. (2002). Photosynthetic characteristics of Thalassia testudinum measured in situ by pulse-amplitude modulated (PAM) fluorometry: methodological and scale-based considerations. Aquat. Bot. 73, 173-185. doi: 10.1016/S0304-3770(02)00020-7

Durako, M. J., Kunzelman, J. I., Kenworthy, W. J., and Hammerstrom, K. K. (2003). Depth-related variability in the photobiology of two populations of Halophila johnsonii and Halophila decipiens. Mar. Biol. 142, 1219-1228. doi: 10.1007/s00227-003-1038-3

Enríquez, S. (2005). Light absorption efficiency and the package effect in the leaves of the seagrass Thalassia testudinum. Mar. Ecol. Prog. Ser. 289, 141-150. doi: 10.3354/meps289141

Enríquez, S., and Pantoja-Reyes, N. I. (2005). Form-function analysis of the effect of canopy morphology on leaf self-shading in the seagrass Thalassia testudinum. Oecologia 145, 234-242. doi: 10.1007/s00442-005-0111-7

Fourqurean, J. W., Escorcia, S. P., Anderson, W. T., and Zieman, J. C. (2005). Spatial and seasonal variability in elemental content, $\delta^{13} \mathrm{C}$, and $\delta^{15} \mathrm{~N}$ of Thalassia testudinum from South Florida and its implications for ecosystem studies. Estuaries 28, 447-461. doi: 10.1007/BF02693926

Genty, B., Briantais, J.-M., and Baker, N. R. (1989). The relationship between the quantum yield of photosynthetic electron transport and quenching of chlorophyll fluorescence. BBA Gen. Subj. 990, 87-92. doi: 10.1016/S0304-4165(89)80016-9

Härtel, H., and Grimm, B. (1998). Consequences of chlorophyll deficiency for leaf carotenoid composition in tobacco synthesizing glutamate 1-semialdehyde aminotransferase antisense RNA: dependency on developmental age and growth light. J. Exp. Bot. 49, 535-546. doi: 10.1093/jxb/49.320.535

Hemminga, M. A., and Duarte, C. M. (2000). Seagrass Ecology. Cambridge: Cambridge University Press.

Hemminga, M. A., and Mateo, M. A. (1996). Stable carbon isotopes in seagrasses: variability in ratios and use in ecological studies. Mar. Ecol. Prog. Ser. 140, 285-298. doi: 10.3354/meps140285

Horton, P., and Hague, A. (1988). Studies on the induction of chlorophyll fluorescence in isolated barley protoplasts. IV. Resolution of non-photochemical quenching. BBA Bioenergetics 932, 107-115. doi: 10.1016/0005-2728(88)90144-2

Huong, T. T. L., Vermaat, J. E., Terrados, J., Van Tien, N., Duarte, C. M., Borum, J., et al. (2003). Seasonality and depth zonation of intertidal Halophila ovalis and Zostera japonica in Ha Long Bay (Northern Vietnam). Aquat. Bot. 75, 147-157. doi: 10.1016/S0304-3770(02)00172-9

Invers, O., Zimmerman, R. C., Alberte, R. S., Pérez, M., and Romero, J. (2001). Inorganic carbon sources for seagrass photosynthesis: an experimental evaluation of bicarbonate use in species inhabiting temperate waters.
J. Exp. Mar. Biol. Ecol. 265, 203-217. doi: 10.1016/S0022-0981(01) 00332-X

Kaldy, J. E., Shafer, D. J., and Magoun, A. D. (2015). Duration of temperature exposure controls growth of Zostera japonica: implications for zonation and colonization. J. Exp. Mar. Biol. Ecol. 464, 68-74. doi: 10.1016/j.jembe.2014.12.015

Kentula, M. E., and McIntire, C. D. (1986). The autecology and production dynamics of eelgrass (Zostera marina L.) in Netarts Bay, Oregon. Estuaries 9, 188-199. doi: 10.2307/1352130

Kim, J.-H., Kim, S. H., Kim, Y. K., and Lee, K.-S. (2016b). Carbon and nitrogen dynamics of the intertidal seagrass, Zostera japonica, on the southern coast of the Korean peninsula. Ocean Sci. J. 51, 635-645. doi: 10.1007/s12601-016-0058-0

Kim, J.-H., Kim, S. H., Kim, Y. K., Park, J.-I., and Lee, K.-S. (2016a). Growth dynamics of the seagrass Zostera japonica at its upper and lower distributional limits in the intertidal zone. Estuar. Coast. Shelf Sci. 175, 1-9. doi: 10.1016/j.ecss.2016.03.023

Kim, M.-S., Lee, S.-M., Kim, H.-J., Lee, S.-Y., Yoon, S.-H., and Shin, K.-H. (2014). Carbon stable isotope ratios of new leaves of Zostera marina in the mid-latitude region: implications of seasonal variation in productivity. J. Exp. Mar. Biol. Ecol. 461, 286-296. doi: 10.1016/j.jembe.2014.08.015

Kim, S. H., Kim, J. W., Kim, Y. K., Park, S. R., and Lee, K.-S. (2020). Factors controlling the vertical zonation of the intertidal seagrass, Zostera japonica in its native range in the Northwestern Pacific. Mar. Environ. Res. 157:104959. doi: 10.1016/j.marenvres.2020.104959

Kim, Y. K., Kim, S. H., and Lee, K. S. (2015). Seasonal growth responses of the seagrass Zostera marina under severely diminished light conditions. Estuar. Coast. 38, 558-568. doi: 10.1007/s12237-014-9833-2

Kohlmeier, D., Pilditch, C. A., Bornman, J. F., and Bischof, K. (2014). Site specific differences in morphometry and photophysiology in intertidal Zostera muelleri meadows. Aquat. Bot. 116, 104-109. doi: 10.1016/j.aquabot.2014.02.011

Kuo, J., and McComb, A. J. (1989). "Seagrass taxonomy, structure, and development," in A Treatise on the Biology of Seagrasses With Special Reference to the Australian Region, eds A. W. D. Larkum, A. J. McComb, and S. A. Shephard (Amsterdam: Elsevier Science Pub.), 6-73.

Lee, K.-S., and Dunton, K. H. (1997). Effect of in situ light reduction on the maintenance, growth, and partitioning of carbon resources in Thalassia testudinum banks ex König. J. Exp. Mar. Biol. Ecol. 210, 53-73. doi: 10.1016/S0022-0981(96)02720-7

Lee, K.-S., Kim, S. H., and Kim, Y. K. (2018). "Current status of seagrass habitat in Korea," in The Wetland Book: II: Distribution, Description, and Conservation, eds C. M. Finlayson, G. R. Milton, R. C. Prentice, and N. C. Davidson (Dordrecht: Springer), 1589-1596.

Lee, K.-S., Park, S. R., and Kim, Y. K. (2007). Effects of irradiance, temperature, and nutrients on growth dynamics of seagrasses: a review. J. Exp. Mar. Biol. Ecol. 350, 144-175. doi: 10.1016/j.jembe.2007.06.016

Lee, K. S., and Lee, S. Y. (2003). "The seagrasses of the Republic of Korea," in World Atlas of Seagrasses: Present Status and Future Conservation. eds E. P. Green, and F. T. Short (Berkeley, CA: University of California Press), 193-198.

Lepoint, G., Dauby, P., Fontaine, M., Bouquegneau, J.-M., and Gobert, S. (2003). Carbon and nitrogen isotopic ratios of the seagrass Posidonia oceanica: depthrelated variations. Bot. Mar. 46, 555-561. doi: 10.1515/BOT.2003.058

Leuschner, C., Landwehr, S., and Mehlig, U. (1998). Limitation of carbon assimilation of intertidal Zostera noltii and $Z$. marina by desiccation at low tide. Aquat. Bot. 62, 171-176. doi: 10.1016/S0304-3770(98)00091-6

Long, M. H., Rheuban, J. E., Berg, P., and Zieman, J. C. (2012). A comparison and correction of light intensity loggers to photosynthetically active radiation sensors. Limnol. Oceanogr. Meth. 10, 416-424. doi: 10.4319/lom.2012. 10.416

Longstaff, B. J., and Dennison, W. C. (1999). Seagrass survival during pulsed turbidity events: the effects of light deprivation on the seagrasses Halodule pinifolia and Halophila ovalis. Aquat. Bot. 65, 105-121. doi: 10.1016/S0304-3770(99)00035-2

Mackey, P., Collier, C. J., and Lavery, P. S. (2007). Effects of experimental reduction of light availability on the seagrass Amphibolis griffithii. Mar. Ecol. Prog. Ser. 342, 117-126. doi: 10.3354/meps342117

Major, K. M., and Dunton, K. H. (2002). Variations in light-harvesting characteristics of the seagrass, Thalassia testudinum: evidence 
for photoacclimation. J. Exp. Mar. Biol. Ecol. 275, 173-189. doi: 10.1016/S0022-0981(02)00212-5

Manassa, R. P., Smith, T. M., Beardall, J., Keough, M. J., and Cook, P. L. M. (2017). Capacity of a temperate intertidal seagrass species to tolerate changing environmental conditions: significance of light and tidal exposure. Ecol. Indic. 81, 578-586. doi: 10.1016/j.ecolind.2017.04.056

Marsh, J. A. Jr., Dennison, W. C., and Alberte, R. S. (1986). Effects of temperature on photosynthesis and respiration in eelgrass (Zostera marina L.). J. Exp. Mar. Biol. Ecol. 101, 257-267. doi: 10.1016/0022-0981(86)90267-4

Mateo, M. A., Renom, P., Hemminga, M. A., and Peene, J. (2001). Measurement of seagrass production using the ${ }^{13} \mathrm{C}$ stable isotope compared with classical $\mathrm{O}_{2}$ and ${ }^{14} \mathrm{C}$ methods. Mar. Ecol. Prog. Ser. 223, 157-165. doi: 10.3354/meps223157

Nellemann, C., and Corcoran, E. (2009). Blue Carbon: The Role of Healthy Oceans in Binding Carbon: A Rapid Response Assessment. Nairobi: UNEP/Earthprint.

Olesen, B., Enríquez, S., Duarte, C. M., and Sand-Jensen, K. (2002). Depthacclimation of photosynthesis, morphology, and demography of Posidonia oceanica and Cymodocea nodosa in the Spanish Mediterranean Sea. Mar. Ecol. Prog. Ser. 236, 89-97. doi: 10.3354/meps236089

Olivé, I., Vergara, J., and Pérez-Lloréns, J. (2013). Photosynthetic and morphological photoacclimation of the seagrass Cymodocea nodosa to season, depth, and leaf position. Mar. Biol. 160, 285-297. doi: 10.1007/s00227-012-2087-2

Orth, R. J., Carruthers, T. J., Dennison, W. C., Duarte, C. M., Fourqurean, J. W., Heck, K. L., et al. (2006). A global crisis for seagrass ecosystems. Bioscience 56, 987-996. doi: 10.1641/0006-3568(2006)56[987:AGCFSE]2.0.CO;2

Park, S. R., Kim, S., Kim, Y. K., Kang, C.-K., and Lee, K.-S. (2016). Photoacclimatory responses of Zostera marina in the intertidal and subtidal zones. PLoS ONE 11:e0156214. doi: 10.1371/journal.pone.0156214

Park, S. R., Li, W.-T., Kim, S. H., Kim, J. W.; and Lee, K.-S. (2010). A Comparison of methods for estimating the productivity of Zostera marina. J. Ecol. Environ. 33, 59-65. doi: 10.5141/JEFB.2010.33.1.059

Pedersen, O., Colmer, T. D., Borum, J., Zavala-Perez, A., and Kendrick, G. A. (2016). Heat stress of two tropical seagrass species during low tides-impact on underwater net photosynthesis, dark respiration, and diel in situ internal aeration. New Phytol. 210, 1207-1218. doi: 10.1111/nph.13900

Platt, T., Gallegos, C., and Harrison, W. G. (1981). Photoinhibition of photosynthesis in natural assemblages of marine phytoplankton. J. Mar. Res. $38,687-701$

Ralph, P. J., Durako, M. J., Enríquez, S., Collier, C. J., and Doblin, M. A. (2007). Impact of light limitation on seagrasses. J. Exp. Mar. Biol. Ecol. 350, 176-193. doi: 10.1016/j.jembe.2007.06.017

Ralph, P. J., and Gademann, R. (2005). Rapid light curves: a powerful tool to assess photosynthetic activity. Aquat. Bot. 82, 222-237. doi: 10.1016/j.aquabot.2005.02.006

Ralph, P. J., Gademann, R., and Dennison, W. C. (1998). In situ seagrass photosynthesis measured using a submersible, pulse-amplitude modulated fluorometer. Mar. Biol. 132, 367-373. doi: 10.1007/s002270050403

Ralph, P. J., Gademann, R., Larkum, A. W. D., and Kühl, M. (2002). Spatial heterogeneity in active chlorophyll fluorescence and PSII activity of coral tissues. Mar. Biol. 141, 639-646. doi: 10.1007/s00227-002-0866-x

Raven, J. A., Johnston, A. M., Kübler, J. E., Korb, R., McInroy, S. G., Handley, L. L., et al. (2002). Mechanistic interpretation of carbon isotope discrimination by marine macroalgae and seagrasses. Funct. Plant. Biol. 29, 355-378. doi: 10.1071/PP01201

Sand-Jensen, K., Prahl, C., and Stokholm, H. (1982). Oxygen release from roots of submerged aquatic macrophytes. Oikos 38, 349-354. doi: 10.2307/3544675

Schubert, N., Freitas, C., Silva, A., Costa, M. M., Barrote, I., Horta, P. A., et al. (2018). Photoacclimation strategies in northeastern Atlantic seagrasses: integrating responses across plant organizational levels. Sci. Rep. 8, 1-14. doi: $10.1038 /$ s41598-018-33259-4

Shafer, D. J., and Kaldy, J. E. (2014). Comparison of photosynthetic characteristics of the seagrass congeners Zostera marina L. and Zostera japonica Ascher. and Graeb. Aquat. Bot. 112, 91-97. doi: 10.1016/j.aquabot.2013. 09.002

Shafer, D. J., Sherman, T. D., and Wyllie-Echeverria, S. (2007). Do desiccation tolerances control the vertical distribution of intertidal seagrasses? Aquat. Bot. 87, 161-166. doi: 10.1016/j.aquabot.2007. 04.003
Short, F. T., Carruthers, T., Dennison, W., and Waycott, M. (2007). Global seagrass distribution and diversity: a bioregional model. J. Exp. Mar. Biol. Ecol. 350, 3-20. doi: 10.1016/j.jembe.2007.06.012

Short, F. T., Kosten, S., Morgan, P. A., Malone, S., and Moore, G. E. (2016). Impacts of climate change on submerged and emergent wetland plants. Aquat. Bot. 135, 3-17. doi: 10.1016/j.aquabot.2016.06.006

Smith, R. D., Dennison, W. C., and Alberte, R. S. (1984). Role of seagrass photosynthesis in root aerobic processes. Plant Physiol. 74, 1055-1058. doi: 10.1104/pp.74.4.1055

Soissons, L. M., van Katwijk, M. M., Peralta, G., Brun, F. G., Cardoso, P. G., Grilo, T. F., et al. (2018). Seasonal and latitudinal variation in seagrass mechanical traits across Europe: the influence of local nutrient status and morphometric plasticity. Limnol. Oceanogr. 63, 37-46. doi: 10.1002/lno. 10611

Suonan, Z., Kim, S. H., Qin, L. Z., and Lee, K.-S. (2017). Reproductive strategy of the intertidal seagrass Zostera japonica under different levels of disturbance and tidal inundation. Estuar. Coast. Shelf Sci. 197, 185-193. doi: $10.1016 /$ i.ecss. 2017.08 .031

Tanaka, Y., and Nakaoka, M. (2004). Emergence stress and morphological constraints affect the species distribution and growth of subtropical intertidal seagrasses. Mar. Ecol. Prog. Ser. 284, 117-131. doi: 10.3354/meps284117

Tanaka, Y., and Nakaoka, M. (2007). Interspecific variation in photosynthesis and respiration balance of three seagrasses in relation to light availability. Mar. Ecol. Prog. Ser. 350, 63-70. doi: 10.3354/meps07103

Touchette, B. W., and Burkholder, J. M. (2000). Overview of the physiological ecology of carbon metabolism in seagrasses. J. Exp. Mar. Biol. Ecol. 250, 169-205. doi: 10.1016/S0022-0981(00)00196-9

Tribble, G. (1981). Reef-basel herbivores and the distribution of two seagrasses (Syringodium filiforme and Thalassia testudinum) in the San Blas Islands (Western Caribbean). Mar. Biol. 65, 277-281. doi: 10.1007/BF003 97122

Van der Heide, T., Bouma, T. J., Van Nes, E. H., Van De Koppel, J., Scheffer, M., Roelofs, J. G. M., et al. (2010). Spatial self-organized patterning in seagrasses along a depth gradient of an intertidal ecosystem. Ecology 91, 362-369. doi: 10.1890/08-1567.1

Van Kooten, O., and Snel, J. F. (1990). The use of chlorophyll fluorescence nomenclature in plant stress physiology. Photosynth. Res. 25, 147-150. doi: 10.1007/BF00033156

Watanabe, M., Nakaoka, M., and Mukai, H. (2005). Seasonal variation in vegetative growth and production of the endemic Japanese seagrass Zostera asiatica: a comparison with sympatric Zostera marina. Bot. Mar. 48, 266-273. doi: 10.1515/BOT.2005.036

Wellburn, A. R. (1994). The spectral determination of chlorophylls $a$ and $b$, as well as total carotenoids, using various solvents with spectrophotometers of different resolution. J. Plant Physiol. 144, 307-313. doi: 10.1016/S0176-1617(11)81192-2

White, A. J., and Critchley, C. (1999). Rapid light curves: a new fluorescence method to assess the state of the photosynthetic apparatus. Photosynth. Res. 59, 63-72. doi: 10.1023/A:1006188004189

Williams, S. L. (1987). Competition between the seagrass Thlassia testudinum and Syringodium filiforme in a Caribbean lagoon. Mar. Ecol. Prog. Ser. 35, 91-98. doi: 10.3354/meps035091

Yabe, T., Ikusima, I., and Tsuchiya, T. (1996). Production and population ecology of Phyllospadix iwatensis Makino. II. Comparative studies on leaf characteristics, foliage structure, and biomass change in an intertidal and subtidal zone. Ecol. Res. 11, 291-297. doi: 10.1007/BF023 47786

Yakovleva, I. M., and Titlyanov, E. A. (2001). Effect of high visible and UV irradiance on subtidal Chondrus crispus: stress, photoinhibition, and protective mechanisms. Aquat. Bot. 71, 47-61. doi: 10.1016/S0304-3770(01)00 $167-\mathrm{X}$

Yamamuro, M., Umezawa, Y., and Koike, I. (2001). Seasonality in nutrient concentrations and stable isotope ratios of Halophila ovalis growing on the intertidal flat of SW Thailand. Limnology 2, 199-205. doi: 10.1007/s10201-0018036-2

York, P. H., Gruber, R. K., Hill, R., Ralph, P. J., Booth, D. J., and Macreadie, P. I. (2013). Physiological and morphological responses of the temperate seagrass Zostera muelleri to multiple stressors: investigating the interactive effects 
of light and temperature. PLoS ONE 8:e76377. doi: 10.1371/journal.pone.00 76377

Zhang, X. M., Zhou, Y., Liu, P., Wang, F., Liu, B. J., Liu, X. J., et al. (2015). Temporal pattern in biometrics and nutrient stoichiometry of the intertidal seagrass Zostera japonica and its adaptation to air exposure in a temperate marine lagoon (China): implications for restoration and management. Mar. Pollut. Bull. 94, 103-113. doi: 10.1016/j.marpolbul.201 5.03 .004

Zieman, J. C. (1974). Methods for the study of the growth and production of turtle grass, Thalassia testudinum König. Aquaculture 4, 139-143. doi: 10.1016/0044-8486(74)90029-5
Conflict of Interest: The authors declare that the research was conducted in the absence of any commercial or financial relationships that could be construed as a potential conflict of interest.

Copyright (c) 2021 Park, Moon, Kim and Lee. This is an open-access article distributed under the terms of the Creative Commons Attribution License (CC BY). The use, distribution or reproduction in other forums is permitted, provided the original author(s) and the copyright owner(s) are credited and that the original publication in this journal is cited, in accordance with accepted academic practice. No use, distribution or reproduction is permitted which does not comply with these terms. 